\title{
Is Tariff Reduction a Viable Strategy for Economic Growth in the Periphery? An Examination of Tariff Interaction Effects in 69 Less Developed Countries
}

\author{
Roy Kwon ${ }^{1}$ \\ University of La Verne \\ roykwon@gmail.com
}

\begin{abstract}
Conventional economic wisdom maintains that the reduction of domestic import restrictions assists in the development of less developed countries. But far from being a settled debate, the empirical research on tariffs and economic growth is much more controversial than is commonly recognized. In fact, so contentious and unsettled is this mode of inquiry that the research of some scholars directly contradicts the findings of others. In light of this difficulty encountered by researchers, the current study argues that the tariff-growth link is best analyzed by exploring the conditional effect of import restrictions on the development of low-income countries. Utilizing a panel dataset with information for 69 less developed countries, the results of this investigation show that tariff interactions with domestic investment and labor participation, respectively, augments the growth-generating impact of these variables. In addition, the constituent terms reveal that domestic investment and labor-force participation produces robust negative associations with economic growth when removing their tariff contingent effects. Taken as a whole, the evidence illustrates the value of exploring the indirect relationship between tariffs and economic growth as well as the potential usefulness of restrictive import policies for development in the periphery.
\end{abstract}

Keywords: tariffs, trade policy, economic growth, less developed countries, peripheral development, political economy, world-economy, world-system theory

Conventional economic wisdom generally maintains that free trade is a major engine of world development. More importantly, open economic policies are considered especially important for less developed countries (LDCs) given their propensity to assist in the transfer of technology, the diffusion of know-how, and the exploitation of comparative advantages (Delong and Summer 1993; Grossman and Helpman 1994; Sachs and Warner 1995). This belief is apparent in work of prominent economists and in the policy prescriptions endorsed by the world's most influential global governance institutions. Indeed, there seems to be a widely held supposition that trade liberalization is the only way the developing world can escape from the bondage of

\footnotetext{
${ }^{1}$ Acknowledgements: The author thanks Christopher Chase-Dunn and Anthony Roberts for their comments on previous iterations of this article. Jackie Smith (the editor) and three anonymous reviewers also provided useful suggestions that greatly enhanced the quality of this paper.
} 
underdevelopment, as it is believed to be "among the more important factors promoting economic growth...in developing countries" (IMF 1997:84).

Given this positive general outlook towards trade liberalization, it is no wonder that the recent explosion of international trade is largely driven by the drastic reduction of national controls over foreign imports (O'Rouke 2002). ${ }^{2}$ As summarized in Figure 1, the world's average tariff rate for imported goods in 1989 was $13.7 \%$, i.e., the average duty collected. This tariff rate steadily decreases for the next twenty years to $7.1 \%$ in 2008 , which is a total reduction of $48.2 \%$ or $2.4 \%$ per annum. Most interesting in this illustration is that the promise of economic growth compels developing nation-states to drastically reduce their tariff duties over this relatively short period. In fact, Figure 1 clearly indicates that the more sizeable tariff reductions over the period in question are made by the lower income nation-states.

Figure 1. The Decline of Tariff Rates in Countries of Various Income Level, 1989-2008

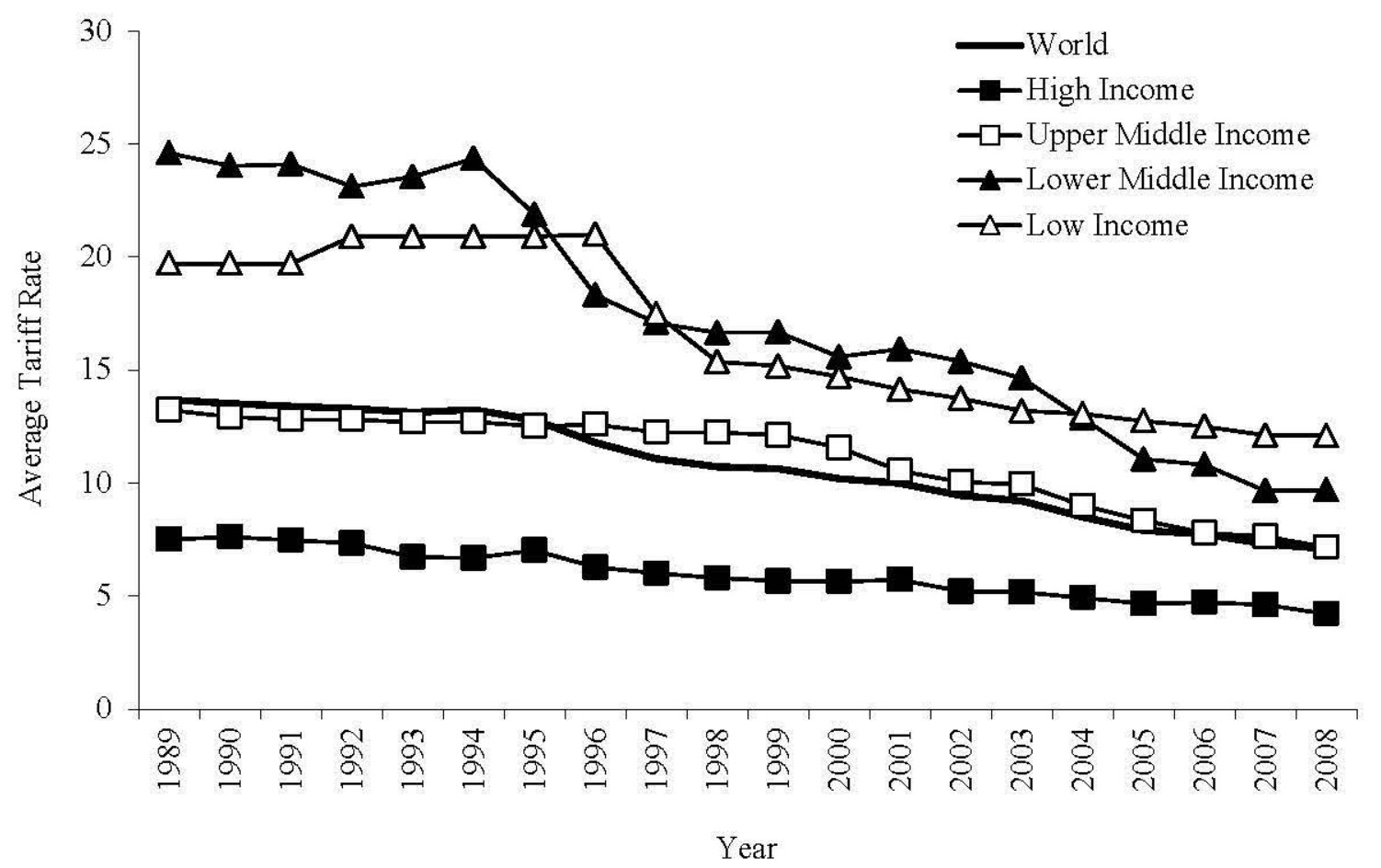

But there is much more controversy surrounding the implications of free trade than the popularity of these tariff reduction trends may reflect. In line with conventional economic wisdom, some scholars find a strong negative relationship between stringent trade policies and economic growth (Lee 1993; Harrison 1996; Edwards 1998). However, others find it difficult to discover a conclusive link between these variables as the evidence indicates a somewhat weak association (Edwards 1992; Sala-i-Martin 1997; Clemens and Williamson 2001). Still others show that open economic policies do not share a robust relationship with growth when geographical variables and institutional quality measures are controlled in the regressions (Rodriguez and Rodrik 2001; Irwin and Tervio 2002; Rodrik et al. 2002). To make matters even more confusing, while researchers report that there is a negative correlation between tariffs and

${ }^{2}$ This is not to say that tariff reductions are the only cause of trade globalization; for recent work in this line of inquiry see Kwon (2012). 
growth in the late- $20^{\text {th }}$ century, they also find a strong positive connection during the early-20 $0^{\text {th }}$ century (Irwin 2002; O'Rouke 2000). This apparent dichotomy in the empirical literature serves as the foundation of a heated academic debate regarding the link between trade policy and development, leading many to question whether there is an actual clear-cut relationship between these variables (e.g., Clemens and Williamson 2002; Yanikkaya 2003). ${ }^{3}$ This sentiment is most clearly stated by Rodriguez and Rodrik (2001: 3-4), who claim that they "are in fact skeptical that there is a general, unambiguous relationship between trade openness and growth waiting to be discovered...[instead], the relationship is a contingent one, dependent on a host of country and external characteristics."

In light of the controversy surrounding this literature, the current investigation explores the potential contingent effects of tariffs on the economic growth of LDCs. Using the work of Raul Prebisch as a theoretical spring-board with which to revisit the question of import restrictions and development in the periphery, this paper extrapolates a set of testable hypotheses designed to examine this connection via a set of interaction effects. In general, this article contends that tariffs protect the domestic economy and aids development by further augmenting the growth-enhancing impact of manufacturing, domestic investment, and labor-force participation. According to the results, interactions of tariffs with domestic investment and laborforce participation, respectively, significantly increases these variables' impact on economic growth. In other words, the findings indicate that the growth-generating effect of domestic investment and labor-force participation increases when combined with a policy of elevated tariffs. What follows is a summary of the historical debate surrounding this controversial literature.

\section{Infant Industries and Unequal Exchange Relations}

The infant-industry argument is one of the oldest economic theories, dating back to the ideas of Alexander Hamilton (1913 [1791]) and prominent economist Frederick List (1856). At the heart of the argument lies the proposition that the poorly capitalized and less sophisticated industries of LDCs require protection against the harms of foreign competition. The potential harm of foreign competition stems from the competitive disadvantage that is characteristic of new firms, given that their economic activities are much more costly than the activities of established firms (Myrdal 1957). Most importantly, the higher cost of production for new firms and industries produces a situation in which the price of free trade goods are not high enough to recoup on its initial investments (Mill 1909).

From these long-standing theoretical origins, the popularity of the infant-industry argument gained particular momentum among Keynesian economists shortly after World War II. Especially influential in this regard is the work of Raul Prebisch, the eventual director of the United Nations Economic Commission for Latin America and the founding secretary general of the United Nations Conference on Trade and Development. According to Prebisch, there is a lack of reciprocity in core-peripheral relations given that the advanced industrial countries selectively implement the idea of comparative advantage. Although rich nation-states advocate for a broad-based reduction of tariffs in LDCs, they simultaneously employ protectionist policies against the import of primary products from the periphery (Prebisch 1959: 264). Problematic is

\footnotetext{
${ }^{3}$ In addition to this less than clear evidence, social scientists also criticize the tariff-growth literature on both methodological and conceptual grounds (e.g., Edwards 1993).
} 
that this core protectionism depresses the development of the periphery, since the primary and manufacturing sectors of rich nation-states are largely self-sufficient, while LDCs remain reliant on the core's industrial production (Love 1980).

Observing these unequal dynamics in core-peripheral relations, Prebisch proposes a set of concrete strategies and policy prescriptions to achieve development in LDCs. First, Prebisch begins with the premise that peripherial development requires a strategy of industrialization. The theory of comparative advantage suggests that it is beneficial for nations to specialize in the production of goods in which they possess the greatest level of labor productivity and resource endowment (Ricardo 1996 [1817]; Heckscher 1944; Ohlin 1966), the implication of which is that the periphery should specialize in the production of primary products. For Prebisch, however, the tendency of primary goods prices to depreciate over time ultimately lends to a decline of domestic incomes and growth in the periphery (Prebisch 1959). Thus, given the long-term decline in the price of primary products, sustained development in LDCs necessitates a strategy of industrialization.

Second, Prebisch agrees with the infant industry argument and claims that the new firms of the periphery must be sheltered against the potential harmful effects of foreign (particularly core) competition. This, of course, is a natural extension of his view that the periphery must transition from primary to industrial modes of production. However, previous iterations of the infant industry argument assert that a strategy of protectionism should only be used to safeguard those specific industries where the domestic cost of production is higher than the imported cost of production (Mill 1909). In contrast, Prebisch maintains that protectionism should be extended to the entire manufacturing sector of the developing economy. More concretely, development in the periphery requires that the entire industrial sector of these nation-states, and not just individual industries, be protected against core competition (Prebisch 1950).

Finally, Prebisch (1959: 256) observes that the higher import prices that are generated by the application of tariffs will "make attractive those new [domestic] branches of industries which were not so before because their costs were higher than import prices." As a result, protectionism in the periphery will cause an expansion of domestic industrial production and generate forms of employment with the capacity to absorb "manpower...to bring higher profits and stimulate expanded production and exports" (Prebisch 1959: 256). The critical observation here is that protectionist policies will create an economic environment in which the increased absorption of workers into the national labor-force will generate higher overall levels of economic growth, as an increasing proportion of the workforce enters into the highly profitable and higher-paying industrial sectors of the domestic economy. ${ }^{4}$

In this way and following these broad policy prescriptions, a large number of developing nations began to experience rapid growth using Prebisch's dual model of industrialization and protectionism (Baldwin 2003: 4-7). Often referred to as import substitution industrialization, Prebisch's ideas earned particular appreciation in the social sciences and his influence on economic policy continued to grow throughout the $1950 \mathrm{~s}$ and 1960 s. So influential were the ideas of Raul Prebisch that he is widely credited with inspiring a major shift in the development literature and is cited as a major foundationary figure of dependency and world-systems theory (see Frank, 1969; Galtung 1971; Emmanuel 1972; Amin 1974; Wallerstein 1974).

\footnotetext{
${ }^{4}$ This observation is similar to the argument made by Kuznets in the context of income inequality. For Kuznets (1955), income inequality is high during the initial stages of industrialization as the well-paid industrial workforce is relatively small compared to the size of the agricultural workforce. But incomes eventually converge with further industrialization as an increasing proportion of the labor-force is converted into industrial labor.
} 


\section{The Wave of Opposition against the Infant Industry Argument}

Gradually over time, however, there grew a sizable theoretical literature that challenged the infant-industry argument. Gaining particular traction in the $1960 \mathrm{~s}$, a number of economists turned Prebisch's arguments on its head by claiming that tariffs actually produce a wide range of damaging effects on the economy of LDCs (Baldwin 1969). Specifically, tariffs are scrutinized by critics given their potential for generating fierce levels of inflation as protectionist policies tend to drive up the price of imported goods. More important is that these inflationary trends in the price of consumer goods can generate a concurrent decrease of domestic consumption, leading to a stagnant economy and lower overall levels of social welfare (Johnson 1965; Baldwin 1969). In addition, others argue that protectionism obstructs the advancement of more industrious production techniques, given that inefficient industries are rewarded with high profit levels that are artificially induced by favorable tariff policies (Turvey 1963; Buchanan 1966; Plott 1966).

Empirical case studies pinpointing the adverse impact of stringent tariff policies soon followed these theoretical works. Earlier case studies tended to concentrate on the effect of import protections for the economic returns of producers that utilize imported goods as an input of production. Examining a limited number of countries and industries, some scholars find that producers who purchase their production inputs at tariff prices garner lower rates of return than those who purchase inputs at free trade prices (Little et al. 1970; Balassa 1971). Still others discover that protected industries experience lower productivity levels than their non-protected counterparts. Scholars involved in this line of research show that output per unit of input is much higher in non-protected industries vis-à-vis protected ones (Krueger and Tuncer 1982).

In addition to these case studies, others find that nations utilizing inward-oriented development strategies, i.e., import substitution industrialization, generate lower levels of economic growth than their outward-oriented counterparts (Bhagwati 1978). For example, Krueger $(1983,1984)$ examines development in four nations that liberalized their national trade policies during the $1960 \mathrm{~s}$ and $1970 \mathrm{~s}$. To this end, the author finds that growth rates are significantly higher after the adoption of free trade policies than they were prior to their ratification. More recently, Dollar and Kraay (2004) perform a similar analysis on a larger set of 16 countries during the $1980 \mathrm{~s}$ to $1990 \mathrm{~s}$, only to find a robust positive association between freer trade policies and economic growth.

This mounting evidence eventually culminated in the establishment of endogenous growth theory, which induced a drastic shift in the sentiment of both economists and policy makers alike. As important advocates of liberalization in LDCs during the 1980s (Baldwin 2003: 12), proponents of the endogenous growth model argue that investments in production, human capital, and technology, are the most vital components of domestic growth (Romer 1986; Lucas 1988). Centrally, it is purported that liberalization plays a particularly important role in the growth of LDCs, given that free trade allows for the transfer of new technologies and the diffusion of know-how via the "learning-by-doing" process (Delong and Summer 1993; Grossman and Helpman 1994). Furthermore, investment in education, i.e., human capital, is considered key since an educated populace is better equipped to contribute to the development of new technologies and absorb the diffusion of know-how that results from trade (Borrow 1991). 


\section{Contingent Tariffs Effects on the Domestic Economy: Hypotheses and Points of Departure}

Much of the contemporary cross-national research on liberalization and development traditionally concentrates on finding a direct relationship between various measures of trade restriction and economic growth. Although some successfully find a robust negative association between tariffs, as well as other protectionist policies, and national growth rates (Dollar 1992; Lee 1993; Sacks and Warner 1995; Harrison 1996; Edwards 1998; Lee et al. 2004), several other studies reveal that this relationship is weak and/or mixed at best (Edwards 1992; Sala-i-Martin 1997; Clemens and Williamson 2001; Rodriguez and Rodrik 2001; Irwin and Tervio 2002; Rodrik et al. 2002; Yanikkaya 2003). But by examining the tariff-growth link directly, these works fail to address some of the major arguments presented by Raul Prebisch and his particular version of the infant industry argument. Worse still, many interpret the somewhat uncertain negative association between tariffs and growth as clear evidence against the implementation of restrictive import policies without a more nuanced consideration of this inherently complex relationship.

Given the lack of clarity in the empirical literature, what is needed is a reassessment of the infant-industry argument and new directions for research can be found in past theoretical propositions. As shown in previous sections, Prebisch did not necessarily see tariffs as being beneficial for peripheral development in-and-of itself. Instead, tariffs are considered beneficial for LDCs given their ability to increase the price of imported goods, which provides the industrial sector of developing economies a sufficient amount of time to mature and eventually compete with core industries. Thus, the infant industry argument explicitly implies that the implementation of tariffs controls, by itself, is not enough to stimulate growth in the periphery. Rather, it is the dual strategy of tariffs and industrial production that is the critical element of inquiry.

Hypothesis 1: Industrialization will produce a greater positive effect on economic growth when combined with higher tariff rates.

It is also possible to naturally extend Prebisch's arguments and apply them to domestic investment and labor-force participation. Beginning with the former, the success produced by tariffs for domestic manufacturing implies that domestic capital investments are generating a higher rate of return. As such, there is no reason to believe that the growth-augmenting effect of tariff protectionism remains isolated in the manufacturing sectors of the periphery. Insofar as tariffs reduce the overall level of competition that is faced by the domestically capitalized firms of the developing economy, high tariff duties are likely to induce elevated rates of return for domestic capital investments, taken as a whole. As to the latter, Prebisch argues that protectionism in the periphery stimulates additional investments in the industrial sector, which allows associated firms to absorb a higher proportion of the traditional labor force. Thus, this social dynamic may stimulate a demographic transfer of the low-paid workforce into those forms of employment that provide higher levels of compensation, thereby increasing average incomes and augmenting economic development. Simply put, restrictive tariff policy protects the industrial sector and encourages its expansion, allowing a higher proportion of the domestic labor force to enter the high-income sector. 
Hypothesis 2: Domestic investment will produce a greater positive effect on economic growth when combined with higher tariff rates.

Hypothesis 3: Labor-force participation will produce a greater positive effect on economic growth when combined with higher tariff rates.

\section{Methods}

The current investigation compiles a panel dataset to study the effect of tariff interactions on economic growth. Only nations classified by the World Bank (2011) as a non-high income country are included in this dataset given the current study's interest in the development of LDCs. ${ }^{5}$ In order to obtain comparable results across all regression models and generate balanced panels, the analysis consists of only those countries with full information for all the variables. Each variable is tested to ensure a normal distribution and all non-normally distributed variables are corrected by way of conversion to their natural logarithm. Utilizing this strategy, the dataset complied for this study provides full information on 69 LDCs for the years 1997 to 2007. All data are from the World Development Indicators (World Bank 2011). For a list of the countries included in the analysis, see Appendix A.

\section{Dependent Variable}

The dependent variable is economic growth, which is the average annual growth rate of a given nation-state from 1997 to $2007 .^{6}$ Recent scholarship indicates that measurements of national incomes are unduly affected by the type of currency conversion technique utilized (for a review see Korzeniewicz et al. 2004). There are two primary methods used by social scientists to measure GDP across nations, exchange rates (FX) and purchasing power parities (PPP). FX peg national incomes to the U.S. dollar but overestimates the value of goods that are traded internationally, which tends to result in the undervaluation of the currencies of poor countries (Firebaugh 2003). PPP calculates income based on a "basket of goods" estimate but is often illsuited for research that examines longer periods of time (Korzeniewicz and Moran 2009). Given these concerns, the current investigation uses estimates based on real domestic GDP. This inflation-adjusted measure of domestic income allows the researcher to measure a given country's annual change in GDP per capita using local currencies, which allows the researcher to avoid the aforementioned currency conversion issue.

\footnotetext{
${ }^{5}$ The World Bank changes its classification of a nation's income category to correspond with shifts in national levels of development. Thus, it is important to note that this study analyzes countries that are categorized as nonhigh income in 1997, i.e., the first year analyzed, regardless of changes in categorization during later years.

${ }^{6}$ This approach is consistent with the strategy of others and is ideal given that it allows for the calculation of average annual growth rates over an extensive period to reduce the volatility that is often present in year-to-year estimations (e.g., Kentor 1998; Kentor and Boswell 2003; Clark 2010, 2008).
} 


\section{Independent Variables}

The dependent variable is regressed on a set of indicators that control for the endogenous growth model and an additional set of predictors that are popular in the development literature. The endogenous growth model sees capital and labor inputs as the central determinants of economic growth (Romer 1986; Lucas 1988; Borrow 1991; Grossman and Helpman 1994). This model is introduced into the regressions by way of three indicators. The first is the log of domestic investment measured as a percent of total GDP. This variable represents the total capital inputs invested in the national economy. The second variable of interest is secondary education, which provides a measure of human capital. This covariate is measured by the total number of students enrolled in secondary educational institutions divided by the total "age relevant" population. The final variable of interest is $\log$ of labor participation, which represents a country's total labor input measured by a nation's total workforce divided by its total population. See Clark (2010) and Kwon (2011) for recent similar applications of the endogenous growth model.

The additional growth predictors are represented by a set of four independent variables, all of which are included in the regressions given their importance in the current investigation and wide usage in the literature. The first is manufacturing, or the total industrial output in a given economy divided by its total GDP. Next is the natural log of trade openness, this indicator calculates the sum of national imports and exports as a proportion of total GDP. FDI inflow is measured as the $\log$ of the total value of foreign direct investment inflows divided by GDP. ${ }^{7}$ Finally, the natural $\log$ of tariff level measures the average duty or fee charged on all foreign imports into the domestic economy. This variable is reported as the average rate collected against the value of all imported goods. Important to mention at this time is that the impending investigation requires a set of three interaction effects that combines the variable tariff level with manufacturing, domestic investment, and labor-force participation, separately.

Finally, multiple sets of dummy variables are employed to control for the effect of spatial autocorrelation; for a discussion see Anselin (1988) and Cliff and Ord (1981). Some scholars note that economic growth and development follows regional patterns. Still others find strong evidence that patterns of growth tend to converge among nation-states with shared free trade agreements (e.g., Ariba and Paelinck 2003; Dezzani 2006). Thus, this study controls for these effects by constructing dummy variables for region as well as membership in various trade agreements. As to the former, the World Bank (2011) classification of regions is used to categorize the countries of this investigation into the groups East Asia and the Pacific, East Europe and Central Asia, Latin America and the Caribbean, Middle East and North Africa, and South Asia, while the region of Sub-Saharan Africa serves as the excluded category. As to the latter, information on the member-states of the ASEAN Free Trade Area (AFTA), Asia-Pacific Trade Agreement (APTA), Central American Integration System (SICA), G-3 Free Trade Agreement (G-3), Southern African Development Community (SADC), Southern Common Market (MERCOSUR), and World Trade Organization (WTO), are obtained through each respective organization's website. Only those countries that were affiliated as of 1997 were denoted as members. Furthermore, the North American Free Trade Agreement (NAFTA) is not included in the analysis as Mexico is the sole LDC in this organization. Finally, while other trade agreements exist, some did not come into existence until after 1997 and are excluded from the investigation (e.g., Greater Arab Free Trade Area).

\footnotetext{
${ }^{7}$ It is important to note that the evidence for FDI on the economic growth of LDCs is inconclusive (for a more recent example see Moran, Graham, and Blomstrom 2005).
} 


\section{Statistical Techniques}

A variant of the lagged dependent variable (LDV) regression technique is utilized to test the hypotheses of this investigation. With traditional LDV models, often simply referred to as "panel" models in the world-system literature, the dependent variable is measured long after the independent variables. What this means is that the dependent is regressed on both its own value and the values of the independent variables, at a much earlier point in time. The value of the LDV design is its ability to establish temporal precedence which substantially negates the potential for contemporaneous reverse causality. Important to note is that LDV studies of economic growth traditionally employ national income, i.e., GDP per capita, as the dependent variable. Problematic with this strategy, of course, is that past LDV studies are modeling for national income and not necessarily economic growth, for a discussion see Babones (2009:99100). However, the hypotheses of this study necessitates that the current investigation models for growth and not level of development. Thus, this study employs the average annual GDP per capita growth rate during the years 1997 to 2007, which is regressed on the independent variables measured during the year 1997.

A number of diagnostics are performed for all the models reported in the analysis to ensure the robustness of results. First, models are tested for outliers using the Hadi procedure with a cutoff of $p<.05$. In an unreported set of regressions, all specifications are re-estimated by removing the identified outliers. But this does not substantially alter the significance of the variables reported nor are the interpretations of the results markedly affected. Alongside the Hadi procedure, the variance inflation factor (VIF) is calculated for the baseline model (model 1) to identify any possible collinearity that may exist between the variables. The VIF scores range from 1.09 to 5.74 for each indicator and the mean is 2.43 . Although this shows that collinearity may be present between some of the variables in the baseline model, the VIF scores are far from severe as they are well below the critical threshold of 10 (Chatterjee, Hadi and Price 2000). Finally, all models are analyzed by utilizing robust standard errors to control for any potential heteroskedasticity patterns in the error terms.

What should be clear from previous sections is that this article's major analytic focus is to assess whether tariffs significantly augment the growth producing-effect of industrialization, domestic investment, and labor-force participation. As such, particular attention will be given to the interaction terms explored in the analysis and the degree to which each variable combination returns significant results for growth. But attention will also be given to the constituent terms of each model as the removal of the tariff interaction effects provides the opportunity to evaluate the unique impact of each variable. This allows for an assessment of how industrialization, domestic investment, and labor-force participation, impacts economic growth when removing their tariff contingent effect.

\section{Results and Discussion}

The summary of results begins here with a preliminary evaluation of the correlations between the dependent and independent variables. The pair-wise correlations summarized in Table 1 shows that secondary education, domestic investment, and manufacturing, are significantly correlated with economic growth. Of particular interest is that tariff levels, while not significant, returns a negative correlation with the dependent variable. But this preliminary analysis provides little 
confidence in the overall strength of the tariff-growth link as the weak correlation of -0.177 and the wide variation displayed in Figure 2 provides less than convincing results. Additional questions regarding the association between tariffs and growth stem from the partial correlations as these variables return a correlation coefficient of -0.008 . Needless to say, these preliminary findings fail to produce confidence in a robust and direct tariff-growth relationship. This uncertain relationship between tariffs and growth, especially when controlling for the impact of the independent variables, may be a sign that this relationship is much more contingent on the effect of alternative variables than is readily recognized in the literature.

Table 1: Correlations for Economic Growth

\begin{tabular}{lcc}
\hline & $\begin{array}{c}\text { Pair-Wise } \\
\text { Correlations }\end{array}$ & $\begin{array}{c}\text { Partial } \\
\text { Correlations }\end{array}$ \\
\hline \hline & & \\
GDP per capita & -0.019 & $\mathbf{- 0 . 4 3 5 * *}^{* *}$ \\
Secondary education & $\mathbf{0 . 3 2 3} * *$ & $\mathbf{0 . 4 5 0} * *$ \\
Domestic investment & $\mathbf{0 . 2 6 3} *$ & 0.127 \\
Labor participation & 0.068 & 0.044 \\
Manufacturing & $\mathbf{0 . 3 3 1} * *$ & $\mathbf{0 . 2 8 0} *$ \\
Trade openness & -0.009 & -0.186 \\
FDI inflow & 0.189 & $\mathbf{0 . 2 3 4 +}$ \\
Tariff level & -0.177 & -0.008 \\
\hline$\dagger p<.10 ;{ }^{*} p<.05 ; * * p<.01$ & &
\end{tabular}

Figure 2. Scatterplot for Economic Growth and Tariff Rates, 1997-2007

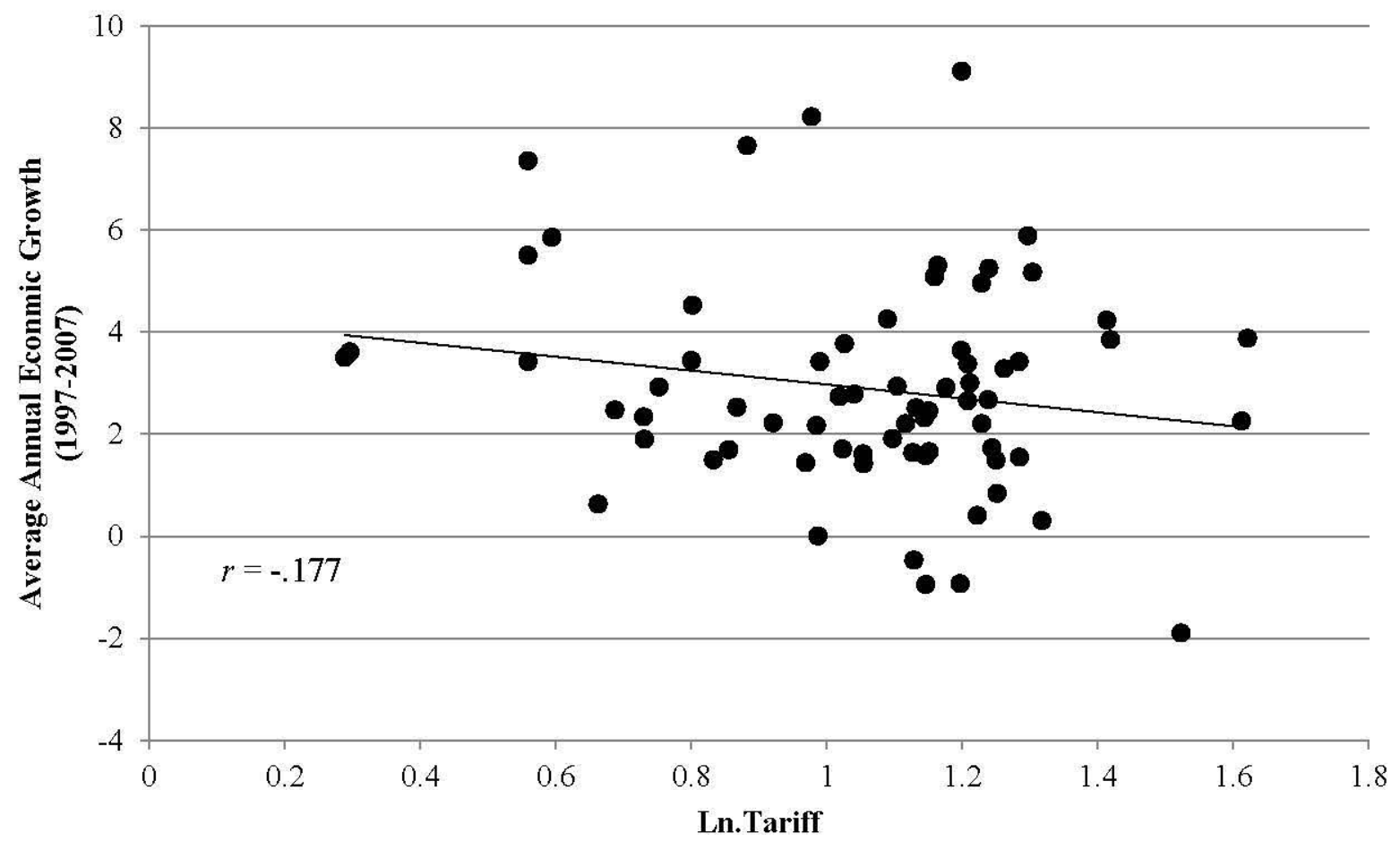


Table 2 reports regressions that explore the interaction effects of various theoreticallyrelevant variables as a way in which to uncover the possible conditional impact of tariffs for economic growth. Beginning with model 1, which serves as this study's baseline model, the results clearly show that tariffs are not a robust predictor of economic growth in LDCs during the period explored. The inability of tariffs to return a significant finding does not come as a surprise given its less than stellar performance in previous studies (Clemens and Williamson 2001; Edwards 1992; Irwin and Tervio 2002; Rodriguez and Rodrik 2001; Rodrik et al. 2002; Sala-iMartin 1997). When observing the other covariates in this baseline model, GDP per capita and secondary education enrolment are significant predictors of the dependent variable and signed in a manner that is consistent with previous research (Romer 1986; Lucas 1988). Particularly interesting is that the independent variables in question are able to obtain a very high level of significance, i.e., $p<.01$. Also noteworthy is that although domestic investment fails to break any level of significance, its coefficient is more than 1.3 times larger than its standard error. Furthermore, this baseline model reveals that both manufacturing and FDI inflow are positively associated with the dependent variable, albeit at a weak $p<.10$ level.

Table 2. Regressions of Economic Growth on Tariff Interaction Terms for 69 Less Developed Countries, 1997-2007

\begin{tabular}{|c|c|c|c|c|}
\hline & 1 & 2 & 3 & 4 \\
\hline GDP per capita & $\begin{array}{l}-\mathbf{3 . 0 0 1} * * \\
(-4.16)\end{array}$ & $\begin{array}{l}-\mathbf{3 . 0 1 9} * * \\
(-4.09)\end{array}$ & $\begin{array}{l}-\mathbf{3 . 0 5 3} * * \\
(-4.49)\end{array}$ & $\begin{array}{l}-\mathbf{2 . 9 8 2} * * \\
(-4.25)\end{array}$ \\
\hline Secondary education & $\begin{array}{l}\mathbf{0 . 0 4 8}^{* *} \\
(3.16)\end{array}$ & $\begin{array}{l}\mathbf{0 . 0 4 8}^{* *} \\
(3.16)\end{array}$ & $\begin{array}{l}\mathbf{0 . 0 3 9 *} \\
(2.52)\end{array}$ & $\begin{array}{l}\mathbf{0 . 0 4 4} \\
(2.89)\end{array}$ \\
\hline Domestic investment & $\begin{array}{r}2.777 \\
(1.36)\end{array}$ & $\begin{array}{l}2.656 \\
(1.31)\end{array}$ & $\begin{array}{l}-\mathbf{1 0 . 4 1 9 *} \\
(-2.19)\end{array}$ & $\begin{array}{r}2.231 \\
(1.11)\end{array}$ \\
\hline Labor participation & $\begin{array}{r}0.769 \\
(0.23)\end{array}$ & $\begin{array}{r}0.589 \\
(0.18)\end{array}$ & $\begin{array}{l}-1.717 \\
(-0.51)\end{array}$ & $\begin{array}{l}-\mathbf{2 3 . 0 8 8}+ \\
(-1.79)\end{array}$ \\
\hline Manufacturing & $\begin{array}{l}\mathbf{0 . 0 6 8 +} \\
(1.69)\end{array}$ & $\begin{array}{l}-0.040 \\
(-0.28)\end{array}$ & $\begin{array}{l}\mathbf{0 . 0 8 0 +} \\
(1.99)\end{array}$ & $\begin{array}{l}\mathbf{0 . 0 7 1 +} \\
(1.73)\end{array}$ \\
\hline Trade openness & $\begin{array}{l}-1.475 \\
(-1.35)\end{array}$ & $\begin{array}{l}-1.259 \\
(-1.12)\end{array}$ & $\begin{array}{l}-1.219 \\
(-1.28)\end{array}$ & $\begin{array}{l}-1.123 \\
(-1.04)\end{array}$ \\
\hline FDI inflow & $\begin{array}{l}\mathbf{2 . 9 4 9 +} \\
(1.93)\end{array}$ & $\begin{array}{l}\mathbf{2 . 8 3 7 +} \\
(1.81)\end{array}$ & $\begin{array}{l}\text { 3.211* } \\
(2.25)\end{array}$ & $\begin{array}{l}\text { 3.201* } \\
(2.18)\end{array}$ \\
\hline Tariff level & $\begin{array}{l}-0.070 \\
(-0.08)\end{array}$ & $\begin{array}{l}-1.844 \\
(-0.71)\end{array}$ & $\begin{array}{l}\mathbf{- 1 6 . 4 6 3} * * \\
(-2.84)\end{array}$ & $\begin{array}{l}-\mathbf{3 5 . 3 1 2} * \\
(-2.02)\end{array}$ \\
\hline Tariff * Manufacturing & & $\begin{array}{r}0.103 \\
(0.76)\end{array}$ & & \\
\hline Tariff * Domestic investment & & & $\begin{array}{l}\text { 12.504** } \\
(2.79)\end{array}$ & \\
\hline Tariff * Labor participation & & & & $\begin{array}{l}19.736^{*} \\
(2.02)\end{array}$ \\
\hline Constant & $\begin{array}{c}4.116 \\
(0.57)\end{array}$ & $\begin{array}{c}\mathbf{6 . 3 1 5} \\
(0.86)\end{array}$ & $\begin{array}{l}\text { 25.598* } \\
(2.42)\end{array}$ & $\begin{array}{l}\mathbf{4 6 . 6 4 5} \text { * } \\
(1.96)\end{array}$ \\
\hline $\begin{array}{l}\mathrm{R}^{2} \\
\text { Observations / Countries }\end{array}$ & $69^{.382}$ & $69^{.386}$ & $69^{.435}$ & $69^{.409}$ \\
\hline
\end{tabular}

Note: Dependent variable is the average annual economic growth rate from 1997 to 2007 ; $\mathrm{t}$-scores are in parentheses; estimates based on robust standard errors. $\nmid p<.10$; $*<<.05 ; * *<<.01$ 
The remaining specifications summarized in Table 2 introduces the interaction terms that test the contingent impact of tariffs for economic growth. Model 2 answers the question of whether higher tariff levels further augment the growth-enhancing effect of industrialization (hypothesis 1). As the most direct assessment of Prebisch's proposed dual strategy of protectionism and industrialization, the findings indicate that the interaction of tariff rates and manufacturing does not produce a robust association with the dependent variable. While signed in the anticipated direction, the paltry t-score of 0.76 fails to break any level of significance and does little to inspire assurance in this interaction's growth-enhancing effect.

Model 3 explores a natural extension of Prebisch's contentions. To reiterate from earlier sections, Prebisch claims that tariffs increase the growth potential of the periphery's domestic industries given their ability to provide protection from foreign competition. However, the current investigation argues that tariffs can also augment the rate of return on domestic investment, given the propensity of tariffs to protect indigenously capitalized firms from core competition (hypothesis 2). According to the findings, the interaction of tariffs and domestic investment returns significant positive association with the dependent variable. Additionally, whereas domestic investment returns a positive coefficient with a t-score of 1.36 in the baseline model, the constituent term for this variable in model 3 returns a significant negative association. This significant negative constituent term warrants heavy emphasis, as this may imply that domestic investment contributes to economic growth only when these investments obtain a certain level of protection from foreign competition.

Model 4 introduces the tariffs and labor participation interaction term into the regressions. This specification tests Prebisch's proposition that tariffs augment economic growth through its ability to foster a higher number of successful domestic firms which, in turn, will absorb the domestic workforce into the high-paid modern sectors of the economy (hypothesis 3 ). Consistent with these arguments, this interaction term returns a positive and significant relationship with the dependent variable. In addition, similar to the results for domestic investment in the previous specification, this particular equation shows that labor participation shares a robust negative correlation with economic growth after removing the tariff contingent effect of this variable.

Table 3 introduces regional control variables to further scrutinize the relationship between the tariff interaction terms and economic growth. A number of interesting observations stem from these set of models. First, there is very little alteration with regards to the interaction of tariffs and domestic investment as its association with the dependent actually increases, from a $\mathrm{t}$-score of 2.79 in model 3 to a $\mathrm{t}$-score of 3.72 in model 6 . However, models 5 and 7 reveal a somewhat substantial change from the previous set of specifications. Beginning with the former, although the interaction of tariffs and manufacturing was not a significant predictor of growth in model 2, this interaction term now returns a positive and significant association in model 5 , albeit at the less conventional $p<.10$ level. Furthermore, while the tariff and labor participation interaction produces a significant association with the dependent variable that surpasses the $p<.05$ level in model 4 , it now returns a level of significance that is only able to break the less conventional $p<.10$ level in model 7. 
Table 3: Regressions of Economic Growth on Tariff Interaction Terms and Regional Controls for 69 Less Developed Countries, 1997-2007

\begin{tabular}{|c|c|c|c|}
\hline & 5 & 6 & 7 \\
\hline GDP per capita & $\begin{array}{l}-1.713+ \\
(-1.78)\end{array}$ & $\begin{array}{l}-2.088^{*} \\
(-2.07)\end{array}$ & $\begin{array}{l}-1.813+ \\
(-1.86)\end{array}$ \\
\hline Secondary education & $\begin{array}{c}0.016 \\
(1.11)\end{array}$ & $\begin{array}{r}0.006 \\
(0.51)\end{array}$ & $\begin{array}{c}0.015 \\
(0.96)\end{array}$ \\
\hline Domestic investment & $\begin{array}{c}4.599^{*} \\
(2.49)\end{array}$ & $\begin{array}{l}-12.367^{* *} \\
(-2.72)\end{array}$ & $\begin{array}{l}3.973^{*} \\
(2.12)\end{array}$ \\
\hline Labor participation & $\begin{array}{c}0.557 \\
(0.17)\end{array}$ & $\begin{array}{c}-2.972 \\
(-0.83)\end{array}$ & $\begin{array}{c}-21.992 \\
(-1.63)\end{array}$ \\
\hline Manufacturing & $\begin{array}{c}-0.231 \\
(-1.28)\end{array}$ & $\begin{array}{r}0.060 \\
(1.58)\end{array}$ & $\begin{array}{c}0.054 \\
(1.30)\end{array}$ \\
\hline Trade openness & $\begin{array}{l}-1.802+ \\
(-1.74)\end{array}$ & $\begin{array}{l}-2.174^{*} \\
(-2.25)\end{array}$ & $\begin{array}{l}-1.906+ \\
(-1.72)\end{array}$ \\
\hline FDI inflow & $\begin{array}{l}4.229^{*} \\
(2.49)\end{array}$ & $\begin{array}{l}4.074^{*} \\
(2.64)\end{array}$ & $\begin{array}{l}4.547^{* *} \\
(2.85)\end{array}$ \\
\hline Tariff level & $\begin{array}{c}-2.697 \\
(-0.88)\end{array}$ & $\begin{array}{l}-19.419^{* *} \\
(-3.55)\end{array}$ & $\begin{array}{l}-33.347+ \\
(-1.79)\end{array}$ \\
\hline Tariff * Manufacturing & $\begin{array}{l}0.269+ \\
(1.68)\end{array}$ & & \\
\hline Tariff * Domestic investment & & $\begin{array}{l}16.483^{* *} \\
(3.72)\end{array}$ & \\
\hline Tariff* Labor participation & & & $\begin{array}{l}19.584+ \\
(1.88)\end{array}$ \\
\hline East Asia and Pacific & $\begin{array}{c}-0.123 \\
(-0.14)\end{array}$ & $\begin{array}{c}0.496 \\
(0.62)\end{array}$ & $\begin{array}{c}0.140 \\
(0.16)\end{array}$ \\
\hline East Europe and Central Asia & $\begin{array}{l}3.680^{* *} \\
(3.69)\end{array}$ & $\begin{array}{l}3.925^{* *} \\
(4.42)\end{array}$ & $\begin{array}{l}3.401 * * \\
(3.39)\end{array}$ \\
\hline Latin America and Caribbean & $\begin{array}{c}-0.158 \\
(-0.25)\end{array}$ & $\begin{array}{c}0.165 \\
(0.27)\end{array}$ & $\begin{array}{c}0.037 \\
(0.06)\end{array}$ \\
\hline Middle East and North Africa & $\begin{array}{c}0.393 \\
(0.67)\end{array}$ & $\begin{array}{c}0.181 \\
(0.34)\end{array}$ & $\begin{array}{r}0.860 \\
(1.33)\end{array}$ \\
\hline South Asia & $\begin{array}{c}-0.288 \\
(-0.34)\end{array}$ & $\begin{array}{c}-0.745 \\
(-0.86)\end{array}$ & $\begin{array}{c}-0.147 \\
(-0.15)\end{array}$ \\
\hline Constant & $\begin{array}{c}1.170 \\
(0.14)\end{array}$ & $\begin{array}{l}26.831 * \\
(2.09)\end{array}$ & $\begin{array}{l}37.709 \\
(1.52)\end{array}$ \\
\hline $\mathrm{R}^{2}$ & .559 & .608 & .555 \\
\hline Observations / Countries & 69 & 69 & 69 \\
\hline
\end{tabular}


Table 4: Regressions of Economic Growth on Tariff Interaction Terms and Trade Agreement Controls for 69 Less Developed Countries, 1997-2007

\begin{tabular}{|c|c|c|c|c|c|c|}
\hline & 8 & 9 & 10 & 11 & 12 & 13 \\
\hline GDP per capita & $\begin{array}{l}\mathbf{- 1 . 5 8 6 +} \\
(-1.90)\end{array}$ & $\begin{array}{l}\mathbf{- 1 . 5 2 7 +} \\
(-1.99)\end{array}$ & $\begin{array}{l}\mathbf{- 1 . 5 4 3 +} \\
(-1.91)\end{array}$ & $\begin{array}{l}-0.294 \\
(-0.30)\end{array}$ & $\begin{array}{l}-0.374 \\
(-0.38)\end{array}$ & $\begin{array}{l}-0.415 \\
(-0.43)\end{array}$ \\
\hline Secondary education & $\begin{array}{c}\mathbf{0 . 0 2 6 +} \\
(1.79)\end{array}$ & $\begin{array}{c}0.014 \\
(1.19)\end{array}$ & $\begin{array}{c}0.022 \\
(1.64)\end{array}$ & $\begin{array}{r}0.019 \\
(1.25)\end{array}$ & $\begin{array}{r}0.010 \\
(0.69)\end{array}$ & $\begin{array}{r}0.017 \\
(1.12)\end{array}$ \\
\hline Domestic investment & $\begin{array}{r}1.748 \\
(0.84)\end{array}$ & $\begin{array}{c}\mathbf{- 1 3 . 0 1 0} \\
(-2.92)\end{array}$ & $\begin{array}{c}1.313 \\
(0.66)\end{array}$ & $\begin{array}{c}2.126 \\
(0.99)\end{array}$ & $\begin{array}{l}\mathbf{- 9 . 5 7 0 +} \\
(-1.82)\end{array}$ & $\begin{array}{c}1.748 \\
(0.83)\end{array}$ \\
\hline Labor participation & $\begin{array}{r}1.145 \\
(0.37)\end{array}$ & $\begin{array}{l}-1.426 \\
(-0.49)\end{array}$ & $\begin{array}{l}\mathbf{- 2 2 . 8 8 7 +} \\
(-1.83)\end{array}$ & $\begin{array}{r}3.416 \\
(1.08)\end{array}$ & $\begin{array}{c}0.968 \\
(0.28)\end{array}$ & $\begin{array}{c}-16.880 \\
(-1.20)\end{array}$ \\
\hline Manufacturing & $\begin{array}{l}-0.024 \\
(-0.19)\end{array}$ & $\begin{array}{l}\mathbf{0 . 0 9 9} \text { ** } \\
(2.99)\end{array}$ & $\begin{array}{l}\mathbf{0 . 0 8 7} \\
(2.55)\end{array}$ & $\begin{array}{l}-0.043 \\
(-0.34)\end{array}$ & $\begin{array}{l}\mathbf{0 . 1 0 6} \text { ** } \\
(3.17)\end{array}$ & $\begin{array}{l}\mathbf{0 . 0 9 8}^{* *} \\
(2.86)\end{array}$ \\
\hline Trade openness & $\begin{array}{l}-1.305 \\
(-1.33)\end{array}$ & $\begin{array}{r}-1.239 \\
(-1.67)\end{array}$ & $\begin{array}{l}-1.165 \\
(-1.25)\end{array}$ & $\begin{array}{l}-\mathbf{2 . 0 6 9} \\
(-2.03)\end{array}$ & $\begin{array}{l}\mathbf{- 2 . 0 2 2 *} \\
(-2.27)\end{array}$ & $\begin{array}{l}\mathbf{- 1 . 8 8 8 +} \\
(-1.75)\end{array}$ \\
\hline FDI inflow & $\begin{array}{l}3.624 \\
(2.30)\end{array}$ & $\begin{array}{l}\text { 4.086** } \\
(2.94)\end{array}$ & $\begin{array}{l}3.995 * * \\
(2.69)\end{array}$ & $\begin{array}{l}4.686^{* *} \\
(3.34)\end{array}$ & $\begin{array}{l}\mathbf{5 . 0 3 9} \text { ** } \\
(3.87)\end{array}$ & $\begin{array}{l}\mathbf{4 . 9 4 8}^{* *} \\
(3.62)\end{array}$ \\
\hline Tariff level & $\begin{array}{l}-1.375 \\
(-0.57)\end{array}$ & $\begin{array}{c}\mathbf{- 1 7 . 9 6 1} \text { ** } \\
(-3.54)\end{array}$ & $\begin{array}{l}\mathbf{- 3 5 . 3 5 8 +} \\
(-1.95)\end{array}$ & $\begin{array}{l}-2.044 \\
(-0.81)\end{array}$ & $\begin{array}{l}\mathbf{- 1 4 . 3 6 4} \\
(-2.41)\end{array}$ & $\begin{array}{c}-30.232 \\
(-1.51)\end{array}$ \\
\hline Tariff * Manufacturing & $\begin{array}{c}0.103 \\
(0.83)\end{array}$ & & & $\begin{array}{r}0.131 \\
(1.09)\end{array}$ & & \\
\hline Tariff * Domestic investment & & $\begin{array}{l}\mathbf{1 4 . 0 4 0}^{* *} \\
(3.58)\end{array}$ & & & $\begin{array}{l}\text { 11.156* }^{*} \\
(2.46)\end{array}$ & \\
\hline Tariff * Labor participation & & & $\begin{array}{l}\mathbf{2 0 . 0 3 3 +} \\
(1.98)\end{array}$ & & & $\begin{array}{l}17.097 \\
(1.53)\end{array}$ \\
\hline WTO & $\begin{array}{l}-\mathbf{1 . 8 9 5} \text { ** } \\
(-3.31)\end{array}$ & $\begin{array}{l}-2.028^{* *} \\
(-3.58)\end{array}$ & $\begin{array}{l}-1.903 \text { ** } \\
(-3.25)\end{array}$ & $\begin{array}{l}-1.911 \text { ** } \\
(-3.18)\end{array}$ & $\begin{array}{l}-\mathbf{2 . 0 5 4} * * \\
(-3.49)\end{array}$ & $\begin{array}{l}-1.843 \text { ** } \\
(-3.04)\end{array}$ \\
\hline ASEAN & & & & $\begin{array}{l}-1.469 \\
(-2.13)\end{array}$ & $\begin{array}{l}-\mathbf{1 . 2 0 3 +} \\
(-1.87)\end{array}$ & $\begin{array}{l}-\mathbf{1 . 5 1 1} \\
(-2.31)\end{array}$ \\
\hline APTA & & & & $\begin{array}{r}1.184 \\
(1.67)\end{array}$ & $\begin{array}{r}1.085 \\
(1.56)\end{array}$ & $\begin{array}{c}0.999 \\
(1.25)\end{array}$ \\
\hline SICA & & & & $\begin{array}{l}-0.156 \\
(-0.29)\end{array}$ & $\begin{array}{l}-0.084 \\
(-0.17)\end{array}$ & $\begin{array}{l}-0.181 \\
(-0.35)\end{array}$ \\
\hline G-3 & & & & $\begin{array}{l}-2.126^{* *} \\
(-3.39)\end{array}$ & $\begin{array}{l}-1.996^{* *} \\
(-3.32)\end{array}$ & $\begin{array}{l}-2.041 \text { ** } \\
(-3.38)\end{array}$ \\
\hline $\mathrm{SADC}$ & & & & $\begin{array}{r}0.119 \\
(0.15)\end{array}$ & $\begin{array}{c}0.198 \\
(0.26)\end{array}$ & $\begin{array}{l}-0.238 \\
(-0.28)\end{array}$ \\
\hline Mercosur & & & & $\begin{array}{l}-\mathbf{2 . 2 4 9} * * \\
(-3.55)\end{array}$ & $\begin{array}{l}-\mathbf{1 . 7 8 7} 7^{* *} \\
(-2.84)\end{array}$ & $\begin{array}{l}-\mathbf{2 . 0 7 1} \text { ** } \\
(-3.36)\end{array}$ \\
\hline Constant & $\begin{array}{c}2.619 \\
(0.37)\end{array}$ & $\begin{array}{l}\text { 24.264* } \\
(2.52)\end{array}$ & $\begin{array}{l}\text { 43.558+ } \\
(1.88)\end{array}$ & $\begin{array}{l}-5.087 \\
(-0.70)\end{array}$ & $\begin{array}{l}12.333 \\
(1.02)\end{array}$ & $\begin{array}{l}28.998 \\
(1.11)\end{array}$ \\
\hline $\mathrm{R}^{2}$ & .483 & .545 & .507 & .589 & .620 & 600 \\
\hline Observations / Countries & 69 & 69 & 69 & 69 & 69 & 69 \\
\hline
\end{tabular}

Note: Dependent variable is the average annual economic growth rate from 1997 to 2007; t-scores are in parentheses; estimates based on robust standard errors

$\uparrow p<.10 ; * p<.05 ; * * p<.01$

A somewhat similar story is revealed in Table 4, which introduces membership in various free trade agreements as an additional way in which to evaluate the robustness of the results. To this end, it is important to note that the interaction of tariffs with labor participation is only able to break the less conventional $p<.10$ significance threshold in model 10 and fails to break 
significance in model 13. Nevertheless, the overall consistency with which this interaction returns significant associations in previous models provides a great deal of confidence in its association with economic growth. Furthermore, the low level of significance obtained by this interaction becomes even more impressive when considering the relatively small sample size and the concurrent large number of covariates included in the model equation. ${ }^{8}$ In addition, although the interaction of tariffs with manufacturing is able to surpass the significance threshold in the previously observed model 5 , this interaction is unable to generate significant results in any other model in which it is included. Most noteworthy, however, is the fact that regardless of the model specifications or variables included in the regression parameters, the interaction of tariffs with domestic investment returns highly significant associations with economic growth. Even more impressive is the fact that the tariff and domestic investment interaction is significant at the very high $p<.01$ in most of the specifications in which it is included.

In sum, the evidence from the regression analysis returns little support for Prebisch's claim that tariffs augment the growth generating effect of manufacturing (hypothesis 1). But the findings also reveal that tariffs are important factors for growth in LDCs given their ability to augment the growth-enhancing effect of domestic investment (hypothesis 2) and labor-force participation (hypothesis 3 ).

\section{Conclusions}

The idea that reduced tariff restrictions stimulate a high rate of development in LDCs is a popular and widely accepted proposition. Consistent with these views, an extensive range of research successfully discovers a direct negative association between various measures of import restriction and economic growth (e.g. Dollar 1992; Lee 1993; Sachs and Warner 1995; Harrison 1996; Edwards 1998; Dollar and Kraay 2004; Lee et al. 2004; Wacziarg and Welch 2008). But this line of research is much more controversial than is commonly recognized, as many engaged in this debate discover an inconsistent and/or weak association between trade policy and growth (e.g., Edwards 1992; Sala-i-Martin 1997; O'Rouke 2000; Clemens and Williamson 2001, 2002; Rodriguez and Rodrik 2001; Irwin 2002; Irwin and Tervio 2002; Rodrik et al. 2002; Yanikkaya 2003). As a result, far from being a settled mode of inquiry, "the nature of the relationship between trade policy and economic growth remains very much an open question" (Rodriquez and Rodrik 2001: 3).

Given the difficultly researchers encounter when analyzing the direct association between these variables, the current study attempts to contribute to this debate by exploring the contingent and indirect impact of tariffs on the economic growth of LDCs. The analysis presented in the current investigation provides support for two of the three hypotheses presented in this study. Specifically, the regression analysis confirms that domestic investment and labor-force participation produces higher rates of economic growth when combined with a strategy of elevated tariffs. Also interesting are the results of the constituent terms, which show that these growth predictors produce a net negative impact on economic growth when controlling for their tariff contingent influence. This latter set of findings is particularly noteworthy and deserves additional commentary.

\footnotetext{
${ }^{8}$ Indeed, it is important to note that potential degrees of freedom issues may be a partial reason for this only moderately significant relationship.
} 
Although it is commonly assumed that there is a uniform set of ideal guidelines to achieve development in both high- and low-income countries, the results in this study reveal that the application of free trade policies in the periphery can contort many of the highly cited factors of growth. For example, domestic capital formation is found by a number of researchers to produce a highly significant and positive impact on the economic development of both core and peripheral nation-states (e.g., Jaffee 1985; Dollar 1992; Firebaugh 1992; Dixon and Boswell 1996; Soysa and Oneal 1999; Clark 2010). Somewhat consistent with this literature, the baseline model of this investigation shows that domestic investment's coefficient is positive and nearly 1.4 times larger than its standard error. It is troubling, however, that this positive association not only dissipates when controlling for the tariff contingent effect of domestic investment, i.e., the interaction of these two indicators, but its coefficient is transformed into a robust negative association. To be clear, it is important to not overstate the implications of these findings. However, the ultimate conclusion to be drawn from this observation is that researchers must avoid sweeping statements regarding the universally beneficial impact of a particular economic strategy. Instead, the current research shows that the usefulness of a particular economic policy is often contingent on the specific needs of an economy and that the reduction of tariffs may generate indirect adverse implications for the development of LDCs.

In closing, this article contributes to the tariffs and growth literature by analyzing tariff interaction dynamics. Although previous studies examine this relationship through a direct assessment of the tariff-growth link, this investigation shows that the benefits of restrictive import policies are much more complex than a direct exploration of this connection is capable of revealing. Thus, it is crucial that future research continues to examine the complex impact of trade policy on economic growth, and explore the manner in which tariffs can be utilized to assist in the development of the periphery. 


\section{Appendix}

Appendix A. Countries Included in the Analysis

\begin{tabular}{lll}
\hline \hline & & \\
Albania & Gabon & Panama \\
Algeria & Ghana & Paraguay \\
Argentina & Guatemala & Peru \\
Bangladesh & Guyana & Philippines \\
Belarus & Honduras & Romania \\
Belize & India & Rwanda \\
Bolivia & Indonesia & Solomon Islands \\
Brazil & Kazakhstan & South Africa \\
Bulgaria & Kenya & Sri Lanka \\
Burkina Faso & Kyrgyz Republic & St. Lucia \\
Cameroon & Lithuania & St. Vincent and Grenadines \\
Central African Republic & Madagascar & Sudan \\
Chad & Malawi & Suriname \\
Chile & Malaysia & Tanzania \\
China & Mali & Thailand \\
Colombia & Mauritius & Tunisia \\
Congo, Rep. & Mexico & Turkey \\
Costa Rica & Moldova & Uganda \\
Cote d'Ivoire & Morocco & Ukraine \\
Dominican Republic & Mozambique & Uruguay \\
Egypt, Arab Rep. & Nepal & Venezuela \\
El Salvador & Nicaragua & Vietnam \\
Ethiopia & Pakistan & Zambia \\
& & \\
\hline
\end{tabular}




\section{References}

Alderson, Arthur S. 1999. "Explaining Deindustrialization: Globalization, Failure, or Success?" American Sociological Review 64: 701-721.

Amin, Samir. 1974. Accumulation on a World Scale. New York: Monthly Review Press.

Anselin, Luc. 1988. Spatial Econometrics: Methods and Models. Boston: Kluwer Academic Publishers.

Arbia, Giuseppe and Jean H.P. Paelinck. 2003. "Economic Convergence or Divergence? Modeling the Interregional Dynamics of EU Regions, 1985-1999." Geographical Systems 5: 1-24.

Babones, Salvatore J. 2009. "Modeling Error in Quantitative Macro-Comparative Research." Journal of World-Systems Research 15(1): 86-114.

Balassa, Bela. 1971. The Structure of Protection in Developing Countries. Baltimore: The Johns Hopkins Press.

Baldwin, Robert E. 2003. "Openness and Growth: What's the Empirical Relationship?" NBER Working Paper \#9578.

Bandelj, Nina and Matthew C. Mahutga. 2010. "How Socio-Economic Change Shapes Income Inequality in Central and Eastern Europe." Social Forces 88(5): 2133-61.

Beckfield, Jason. 2006. "European Integration and Income Inequality." American Sociological Review 71: 964-985

Bhagwati, Jagdish. 1978. Foreign Trade Regimes and Economic Development: Anatomy and Consequences of Exchange Control Regimes. New York: National Bureau of Economic Research.

Bollen, Kenneth A. 1983. "World System Position, Dependency, and Democracy: The CrossNational Evidence." American Sociological Review 48(4):468-479.

Bollen, Kenneth A. and Stephen J Appold. 1993. "National Industrial Structure and the Global System." American Sociological Review 58:283-301.

Borrow, Robert J. 1991. "Economic Growth in a Cross Section of Countries." Quarterly Journal of Economics 106(2): 407-443.

Buchanan, James M. 1966. "Joint Supply, Externality, and Optimality." Economica 23: 404-415.

Chase-Dunn, Christopher. 1975. "The Effects of International Economic Dependence on Development and Inequality: A Cross-National Study." American Sociological Review 40: $720-738$.

----. 1998. Global Formation: Structures of the World-Economy. Lanham, MD: Rowman \& Littlefield Publishers.

Chatterjee, Samprit, Ali Hadi and Bertram Price. 2000. Regression Analysis by Example. $3^{\text {rd }}$ Edition. Hoboken, NJ: John Wiley \& Sons.

Chirot, Daniel. 1977. Social Change in the Twentieth Century. New York: Harcourt Brace Jovanovich.

Clark, Rob. 2008. "Dependency, Network Integration, and Development." Sociological Perspectives 51(3): 629-648.

-----. 2010. "World-System Mobility and Economic Growth, 1980-2000." Social Forces 88(3): 1123-1151.

Clark, Rob and Jason Beckfield. 2009. "A New Trichotomous Measure of World-System Position using the International Trade Network." International Journal of Comparative Sociology 50(5): 5-38. 
Cliff, Andrew D. and J K. Ord. 1981. Spatial Processes. London: Pion.

DeLong, J. Bradford and Lawrence H. Summers. 1993. "How Strongly Do Developing Countries Benefit from Equipment Investment?" Journal of Monetary Economics 32: 395-415.

Dezzani, Raymond. 2006, "The Welfare Benefits of Proximity: The Economic Gains from Trade Bloc Membership." Pp. 61-87 in Structural Change in Transportation and Communications in the Knowledge Society, edited by K. Kobayashi, T.R. Lakshmanan, and W.P. Anderson. Northampton, MA: Edward Elgar.

Dixon, William J. and Terry Boswell. 1996. "Dependency, Disarticulation, and Denominator Effects: Another Look at Foreign Capital Penetration." American Journal of Sociology 102: 543-562

Dollar, David. 1992. "Outward-Oriented Developing Economies Really Do Grow More Rapidly: Evidence from 95 LDCs, 1976-85." Economic Development and Cultural Change 40(3): 523-544.

Dollar, David, and Aart Kraay. 2004. "Trade, Growth, and Poverty." The Economic Journal 114: F22-F49.

Edwards, Sebastian. 1992. "Trade Orientation, Distortions and Growth in Developing Countries." Journal of Development Economics 39: 31-57.

----. 1993. "Openness, Trade Liberalization, and Growth in Developing Countries." Journal of Economic Literature 31(3): 1358-1393.

-----. 1998. "Openness, Productivity and Growth: What Do We Really Know?" Economic Journal 108: 383-398.

Emmanuel, Arighi. 1972. Unequal Exchange. New York: Monthly Review Press.

Firebaugh, Glenn. 1992. "Growth Effects of Foreign and Domestic Investment." American Journal of Sociology 98(1): 105-130.

Firebaugh, Glenn. 2003. The New Geography of Global Income Inequality. Cambridge, MA: Harvard University Press.

Frank, Andre Gunder. 1969. Capitalism and Underdevelopment in Latin America: Historical Studies of Chile and Brazil. New York: Monthly Review Press.

-----. 1978. World Accumulation, 1492-1789. New York: Monthly Review Press

Galtung, Johan. 1971. "A Structural Theory of Imperialism." Journal of Peace Research 8(1): 81-117

Grossman, Gene M. and Elhanan Helpman. 1994. "Endogenous Innovation in the Theory of Growth." The Journal of Economic Perspectives 8(1): 23-44.

Halaby, Charles. 2004. "Panel Models in Sociological Research: Theory into Practice." Annual Review of Sociology 30: 507-544.

Hamilton, Alexander. 1913 [1791]. Report on Manufactures. U.S. Senate Documents, Vol. XXII, No. 172. Washington, DC: Congress.

Harrison, Ann. 1996. "Openness and Growth: A Time-Series, Cross-Country Analysis for Developing Countries." Journal of Development Economics 48: 419-447.

Heckscher, Eli. 1949. "The Effect of Foreign Trade on the Distribution of Income." Readings in the Theory of International Trade, edited by H. S. Ellis and L. A. Metzler. Philadelphia: The Blakiston Co.

Hummels, David. 2007. "Transportation Costs and International Trade in the Second Era of Globalization." Journal of Economic Perspectives 21(3): 131-154. 
International Monetary Fund. 1997. World Economic Outlook. Washington, DC: International Monetary Fund.

----. 2010. World Economic Outlook. Washington, DC: International Monetary Fund.

Irwin, Douglass A. 2002. "Did Import Substitution Promote Growth in the Late Nineteenth Century?" American Economic Review 92(2): 165-169.

Irwin, Douglass A., Marko Tervio. 2002. "Does Trade Raise Income? Evidence from the Twentieth Century." Journal of International Economics 58: 1-18.

Jaffee, David. 1985. "Export Dependence and Economic Growth: A Reformulation and Respecification." Social Forces 64(1): 102-118.

Johnson, H.G. 1965. "Optimal Trade Intervention in the Presence of Domestic Distortions." In Trade, Growth, and the Balance of Payments: Essays in Honor of Gottfried Haberler, edited by Robert E. Baldwin. Chicago: Rand McNally.

Kentor, Jeffrey. 1998. "The Long-Term Effects of Foreign Investment Dependence on Economic Growth, 1940-1990." American Journal of Sociology 103(4): 1024-1046.

Kentor, Jeffrey and Terry Boswell. 2003. "Foreign Capital Dependence and Development: A New Direction." American Sociological Review 68: 301-313.

Kick, Edward and Byron Davis. 2001. "World-System Structure and Change: An Analysis of Global Networks and Economic Growth across Two Time Periods." American Behavioral Scientist 44: 1561-78.

Korzeniewicz, Roberto P., Angela Stach, Vrushali Patil, and Timothy P. Moran. 2004. "Measuring National Income: A Critical Assessment." Comparative Studies in Society and History 46(3): 535-586.

Korzeniewicz, Roberto P. and Timothy P. Moran. 2009. Unveiling Inequality: A WorldHistorical Perspective. New York: Russell Sage Foundation.

Krueger, Anne O. 1983. "The Effects of Trade Strategies on Growth." Finance and Development 20: 6-8.

-----. 1984. "Trade Policies in Developing Countries." Pp. 519-570 in Handbook of International Economics, Volume 1, Ronald Jones and Peter Kenan. Amsterdam: NorthHolland.

Krueger, Anne O., and Baran Tuncer. 1982. "An Empirical Test of the Infant Industry Argument." American Economic Review 72(5): 1142-1152.

Kuznets, Simon. 1955. "Economic Growth and Income Inequality." The American Economic Review 45(1): 1-28.

Kwon, Roy. 2011. "How the Legacy of French Colonization has Shaped the Divergent Levels of Economic Development in East Asia: A Time-Series Cross-National Analysis." Sociological Quarterly 52(1): 56-82.

-----. 2012. "Hegemonic Stability, World Cultural Diffusion, and Trade Globalization." Sociological Forum 27(2): 324-347.

Lee, Cheol-Sung. 2005. "Income Inequality, Democracy, and Public Sector Size." American Sociological Review 70: 158-181.

Lee, Ha Yan, Luca Antonio Ricci, and Roberto Rigobon. 2004. "Once Again, is Openness Good for Growth?" Journal of Development Economics 75(2): 451-472.

Lee, Jong-Wha. 1993. "International Trade, Distortions, and Long-Run Economic Growth." IMF Staff Papers 40(2): 299-328.

List, Frederick. 1856. National System of Political Economy. Philadelphia: Lippincott. 
Little, Ian, Tibor Scitovsky, and Maurice Scott. 1970. Industry and Trade in Some Developing Countries: A Comparative Study. Oxford: Oxford University Press.

Love, Joseph L. 1980. "Raul Prebisch and the Origins of the Doctrine of Unequal Exchange." Latin American Research Review 15(3): 45-72.

Lucas, Robert E. 1988. "On the Mechanics of Economic Development." Journal of Monetary Economics 22: 3-42.

Maddala, G.S. 2001. Introduction to Econometrics. $3^{\text {rd }}$ ed. Hoboken, NJ: John Wiley \& Sons.

Moran, Theodore H., Edward M. Graham, and Magnus Blomstrom. 2005. Does Foreign Direct Investment Promote Development? Washington, DC: Peterson Institute.

Myrdal, Gunnar. 1957. Rich Lands and Poor. New York: Harper.

Nemeth, Roger and David Smith. 1985. "International Trade and World-System Structure: A Multiple Network Analysis." Review 8: 517-60.

Ohlin, Bertil. 1966. Interregional and International Trade. Cambridge, MA: Harvard University Press.

O'Rourke, Kevin H. 2000. "Tariffs and Growth in the Late Nineteenth Century." Economic Journal 110: 456-483.

O'Rourke, Kevin H. 2002. "Europe and the Causes of Globalization, 1790-2000." Pp. 64-86 in From Europeanization of the Globe to the Globalization of Europe, edited by $\mathrm{H}$. Kierzkowski. Hampshire: Palgrave.

Plott, Charles R. "Externalities and Corrective Taxes." Economica 23: 84-87.

Prebisch, Raul. 1950. The Economic Development of Latin America and its Principal Problems. New York: United Nations Department of Economic Affairs.

-----. 1959. "Commercial Policy in the Underdeveloped Countries." American Economic Review 49: $251-273$

Ricardo, David. 1996 [1817]. Principles of Political Economy and Taxation. New York: Prometheus Books.

Rodrik, Dani, Arvind Subramanian, and Francesco Trebbi. 2002. "Institutions Rule: The Primacy of Institutions over Geography and Integration in Economic Development." Journal of Economic Growth 9(2): 131-165.

Rodriguez, Francisco and Dani Rodrik. 2001. "Trade Policy and Economic Growth: A Skeptic's Guide to the Cross-National Evidence." In NBER Macroeconomics Annual 2000, edited by B.S. Bernanke and K. Rogoff. Cambridge, MA: MIT Press.

Romer, Paul M. 1986. "Increasing Returns and Long-run Growth." Journal of Political Economy 94: 1002-1037.

Sachs, Jeffrey, and Andrew Warner. 1995. "Economic Reform and the Process of Global Integration." Brookings Papers on Economic Activity 1: 1-118.

Sala-i-Martin, Xavier. 1997. "I Just Ran Two Million Regressions." American Economic Review 87: 178-183.

Snyder, David and Edward Kick. 1979. "Structural Position in the World System and Economic Growth, 1955-1970: A Multiple-Network Analysis of Transnational Interactions." The American Journal of Sociology 84(5): 1096-1126.

Soysa, Indra de and John R. Oneal. 1999. "Boon or Bane? Reassessing the Productivity of Foreign Direct Investment." American Sociological Review 64(5): 766-782.

Stokes, Randall and Andy Anderson. 1990. "Disarticulation and Human Welfare in Less Developed Countries." American Sociological Review 55: 63-74. 
Turvey, Ralph. 1963. "On Divergence Between Social Cost and Private Cost." Economica 30: 309-313.

Wacziarg, Romain and Karen Horn Welch. 2008. "Trade Liberalization and Growth: New Evidence." World Bank Economic Review 22(2): 187-231.

Wallerstein, Immanuel. 1974. The Modern World System I: Capitalist Agriculture and the Origins of the European World Economy in the Sixteenth Century. New York: Academic Press.

Wickrama, K. A. S. and Charles Mulford. 1996. "Political Democracy, Economic Development, Disarticulation, and Social Well-Being in Developing Countries." Sociological Quarterly 37: $375-390$.

Wooldridge, Jeffery M. 2002. Econometric Analysis of Cross Section and Panel Data. Cambridge, MA: MIT Press.

World Trade Organization. 2008. World Trade Report 2008: Trade in a Globalizing World. Geneva: WTO Publications.

World Bank. 2011. World Development Indicators [online]. Washington DC: World Bank.

Yanikkaya, Halit. 2003. "Trade Openness and Economic Growth: A Cross-Country Empirical Investigation." Journal of Development Economics 72: 57-89. 